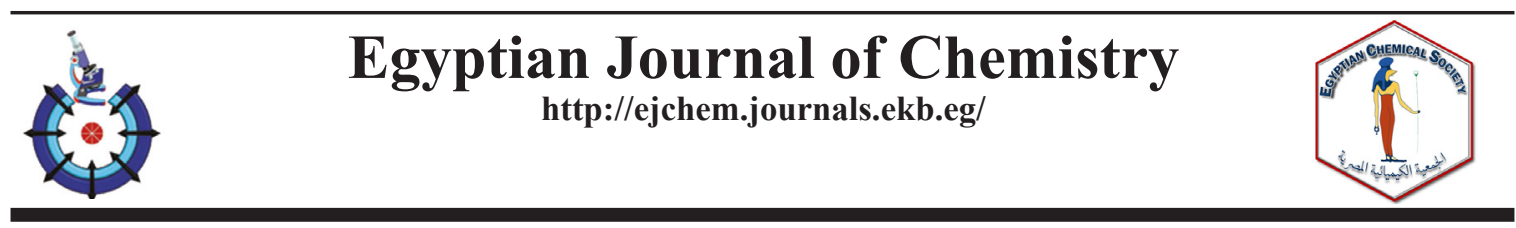

\title{
Analysis of Structural, Electrical and Electronic Properties of (Polymer Nanocomposites/ Silicon Carbide) for Antibacterial Application
}

\author{
Hind Ahmed ${ }^{1}$, Ahmed Hashim ${ }^{* *}$ and Hayder M. Abduljalil ${ }^{2}$ \\ ${ }^{1}$ Department of Physics, College of Education for Pure Sciences, University of \\ Babylon, Iraq. \\ ${ }^{2}$ Department of Physics, College of Science, University of Babylon, Iraq.
}

\begin{abstract}
T HE structural, electronic and D.C electrical properties of (PVA-MgO-SiC) nanocomposites for antibacterial application have been investigated. The prepared nanocomposites have low cost, flexible and high antibacterial activity. The (PVA-MgO-SiC) nanocomposites were prepared with different weight percentages of Silicon Carbide ( $\mathrm{SiC}$ ) nanoparticles. Electrical properties of (PVA-MgO-SiC) nanocomposites were studied with different temperature. The experimental results showed that the conductivity of (PVA-MgO-SiC) nanocomposites is increased with increase the concentration of Silicon Carbide $(\mathrm{SiC})$ nanoparticles. The activation energy of (PVA-MgO-SiC) nanocomposites decreases with increase the weight percentages of Silicon Carbide nanoparticles. The total energies of the (PVA-MgO-SiC) nanocomposites were studied by using Gaussian 09 (G09) program and density functional theory (DFT) with B3LYP/6-31G) basis set. The total energies decreases with the increase the number of atoms forming the nanocomposites .
\end{abstract}

Keywords: Transition metals, Density functional theory, Activation energy, Antibacterial.

\section{Introduction}

Studies on the electrical properties of polymers have involved greatly attention for their applications in electronic and optical devices [1]. Electrical conduction in polymers has been widely studied to understand the nature of charge movable through polymers chain [2]. In previous years, polymers have been used as insulators for their high resistivity and dielectric properties [3]. The studies of D.C electrical conductivity are intended at perception the numbers of the charge carrying species, their source and the method in which they transfer through the material. These factors are connected to the chemical composition, microstructure and morphology of the material [4]. Nanoparticles on the basis of semiconductor nanoparticles and the polymer matrix are future materials for application in optoelectronics [5], sensor electronics, for forming of luminescent materials [6]. Introducing semiconductor nanoparticles into polymer matrix volume changes physicochemical properties of the system. The properties of gotten structures rely on a semiconductor particle type, dimensions of particles. Also, the physicochemical properties of the system will be under influence of the effects of interaction of polymer matrix with nanoparticles [7]. The construction of nanocomposites can be carried out in many ways [8]. Technology of procurement nanocomposites can effect on distribution of nanoparticles in dimensions of nanoparticles, polymer matrix volume and etc. All these elements may owing to change in physicochemical properties of the system[9]. Magnesium oxide $(\mathrm{MgO})$ known as magnesia is a beneficial material used in many fields as ceramics, catalysis, and refractory as well as paint industry [10]. $\mathrm{MgO}$ is an important inorganic oxide and has been widely used in numerous fields. Abundant studies have illustrated that $\mathrm{MgO}$ nanoparticles have well antibacterial

*Corresponding author e-mail: ahmed taay@yahoo.com

Received 16/11/2018; Accepted 14/1/2019

DOI: 10.21608/EJCHEM.2019.6241.1522

(C)2019 National Information and Documentation Center (NIDOC) 
activity [11]. For high temperature structural components the Silicon Carbide ( $\mathrm{SiC}$ ) considered one of the favorable filter ceramics for its excellent mechanical, electrical and thermal properties such as fracture strength, great elastic modulus, hardness and toughness, relatively low density, chemical stability and well thermal properties as well as low thermal expansion coefficient and high resistivity [12]. A combination of $\mathrm{SiC}$ with metals/metal oxides compensates its brittleness and expands its engineering applications. [13]. Without addition of any metal or metal oxide as sintering aids, it will be very difficult to sinter pure form $\mathrm{SiC}$ through conventional heating technique because $\mathrm{SiC}$ needs a higher temperature above $\left(2000^{\circ} \mathrm{C}\right)$ to be sintered. The oxide phase greatly decreases the sintering temperature and advances the fracture toughness of the materials[14]. Numerous transition metal carbides (TMCs) have good mechanical and chemical stability and resistance against corrosion under reaction condition [15]. Now, several of the inorganic antibacterial materials, in specific inorganic metal oxides like $\mathrm{MgO}, \mathrm{ZnO}, \mathrm{TiO}_{2}$ and $\mathrm{CaO}$, have been studied [16]. Metal oxide nanoparticles like $\mathrm{MgO}$, $\mathrm{ZnO}$ and $\mathrm{CaO}$ have been studied as inorganic antibacterial factor[11]. Density functional theory(DFT) has acquired substantial ground in last few years to become one of the greatest most used methods for the calculation of molecular structure. Its Features comprise less demanding computational effort, low computer time, and in some cases better agreement with experimental values than is gotten from other procedures [17]. nFT frouses on the much simpler electron density $\rho(\square)$. In general, the electron density is the number of electrons $\mathrm{N}$ per unit volume for a given state [18]. All of the computational calculations were performed using the Gaussian 09 RevisionA.02 SMP suite of program with GUI (Graphical user Interface) called Gauss view, version 5.0.8 (GV5 for short) [19]. And Gaussian 03 Revision B.01 with Gauss view 3.07(GV3for short) [20].

The effect of Silicon Carbide (SiC) nanoparticles on electrical properties of (PVA$\mathrm{MgO}-\mathrm{SiC}$ ) nanocomposites and their application has been treated in this paper. The (PVA-MgO) nanocomposites and Silicon Carbide (SiC) nanoparticles are used because of their properties: good electrical properties, high mechanical and thermal properties, good antibacterial activity, low cost and flexible. The suitable lower concentration of $\mathrm{MgO}$ with good properties and applications is $(1.5 \mathrm{wt} \%$ ) from PVA.

\section{Experimental}

Polyvinyl alcohol-Silicon CarbideMagnesium oxide nanocomposites were prepared by using casting technique with weight percentage of polymer PVA is (98.5 wt.\%) and (1.5 wt.\%) Magnesium oxide nanoparticles. Nanocomposites of (PVA-MgO-SiC) were prepared with different weight percentages of Silicon Carbide nanoparticles (1.5, 3, 4.5 and 6 wt.\%). The electrical resistivity of (PVA-MgO$\mathrm{SiC})$ nanocomposites was measured at different temperatures from $\left(50\right.$ to $\left.80^{\circ} \mathrm{C}\right)$ using Keithly electrometer type (2400 source mater).

The D.C electrical conductivity (r) of (PVA$\mathrm{MgO}-\mathrm{SiC}$ ) nanocomposites is calculated by following equation [21]:

$$
\sigma=\frac{d}{R} \quad \ldots . .
$$

Where $\mathrm{A}=$ effective area $\left(\mathrm{cm}^{2}\right), \mathrm{R}=$ resistance $(\mathrm{Ohm}), d=$ thickness of sample $(\mathrm{cm})$.

The activation energy for (PVA-MgO-SiC) nanocomposites is defined by [22]:

$$
\sigma=\sigma_{o} \exp \left(-E_{a c t} / K_{B} T .\right)
$$

$\sigma=$ electrical conductivity at $\mathrm{T}$ temperature , $\sigma_{0}=$ electrical conductivity at absolute zero of temperature, $\mathrm{K}_{\mathrm{B}}=$ Boltzmann constant, $\mathrm{E}_{\mathrm{act}}=$ activation energy.

\section{$\underline{\text { Results and Discussion }}$}

Figure 1 shows the effect of addition of Silicon Carbide ( $\mathrm{SiC}$ ) nanoparticles concentration on electrical conductivity of (PVA-MgO). The figure indicated that the electrical conductivity is increased with the increase of Silicon Carbide nanoparticles concentration. This conduct connected to the Silicon Carbide nanoparticles and (PVA-MgO-SiC) nanocomposites having great number of free charge carriers obtainable for the aim of conduction. Hence, as the concentration of Silicon Carbide nanoparticles increases the number of free charge carriers also increases [23], as shown in Fig. 2 and 3. The figures show that the $\mathrm{SiC}$ nanoparticles are aggregated as clusters at lower concentrations. When increasing the concentrations of $\mathrm{SiC}$ nanoparticles, the nanoparticles form a paths network inside the PVA.

The relationship between the $\ln (\sigma)$ and inverted absolute temperature of (PVA- 


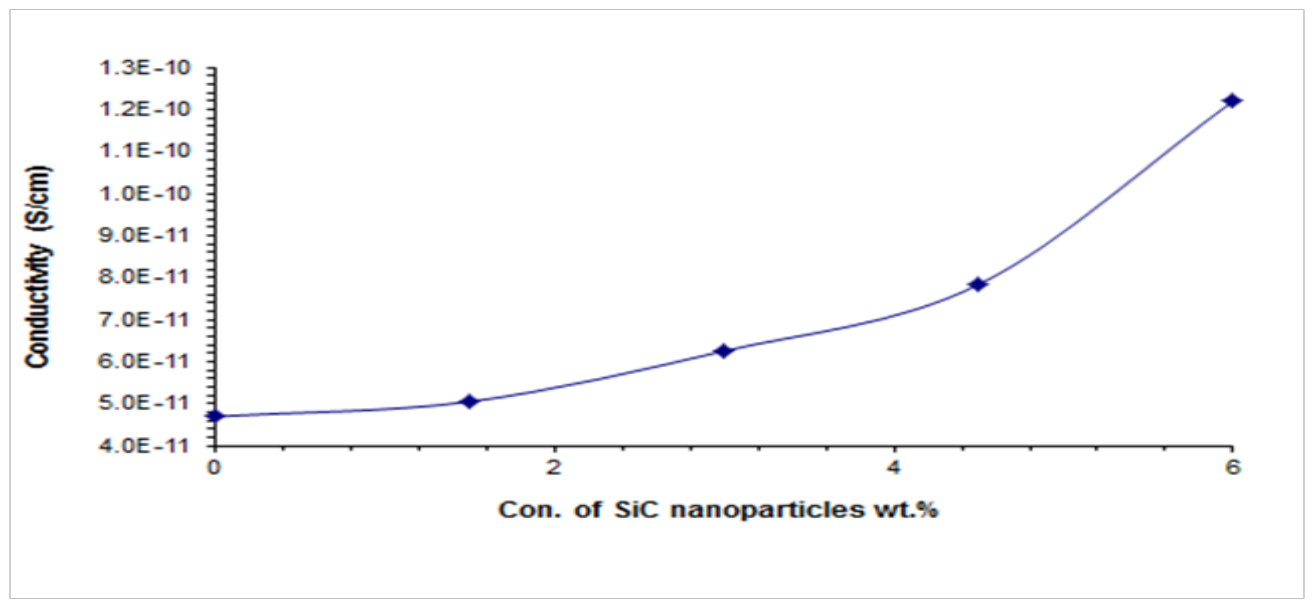

Fig. 1. Effect of $\mathrm{SiC}$ nanoparticles concentrations for (PVA-MgO-SiC) nanocomposites on D.C electrical conductivity.
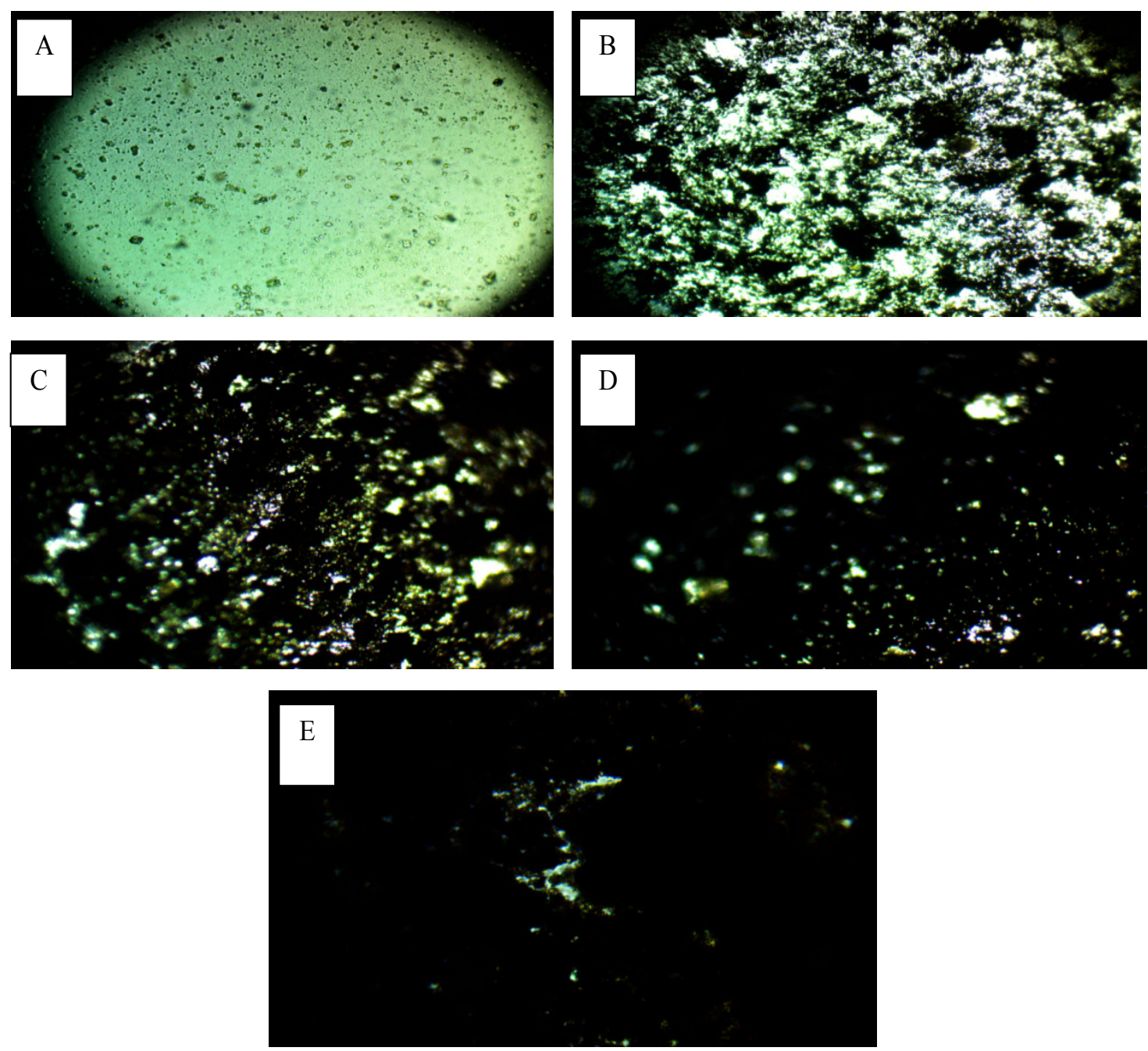

Fig. 2. Photomicrographs $(\times 10)$ for $(\mathrm{PVA}-\mathrm{MgO}-\mathrm{SiC})$ nanocomposites. A- For pure, B- for $1.5 \mathrm{wt} \% \mathrm{SiC}$ nanoparticles, C- for 3, wt\% SiC nanoparticles, D-, for $4.5 \mathrm{wt} \% \mathrm{SiC}$ nanoparticles, E-for $6 \mathrm{wt} \% \mathrm{SiC}$ nanoparticles . 

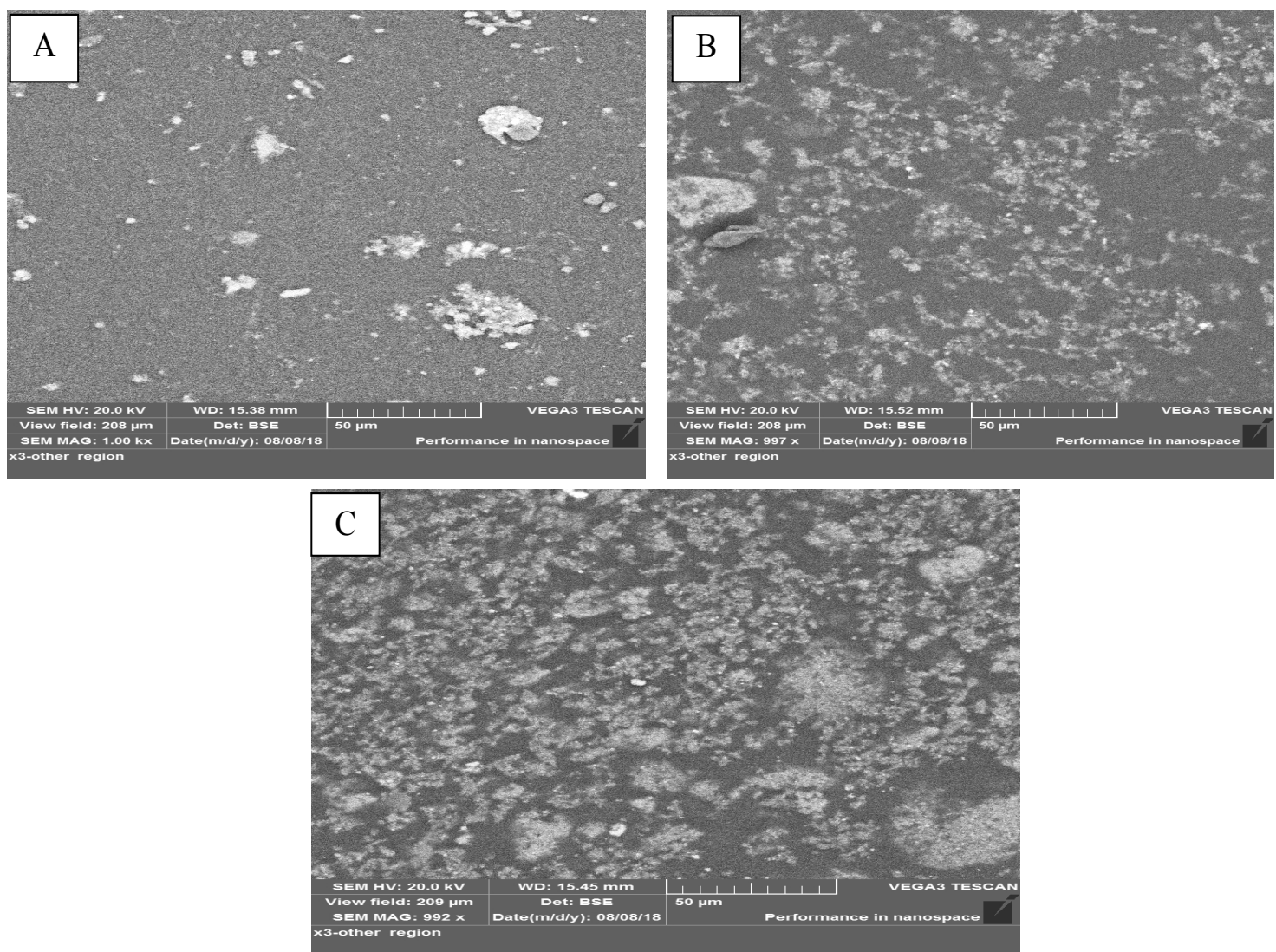

Fig. 3. SEM images of (PVA-MgO-SiC), nanocomposites, (A), for pure (PVA-MgO) (B) for 1.5 wt.\% SiC nanoparticles, (C) for $6 \mathrm{wt} . \% \mathrm{SiC}$, nanoparticles

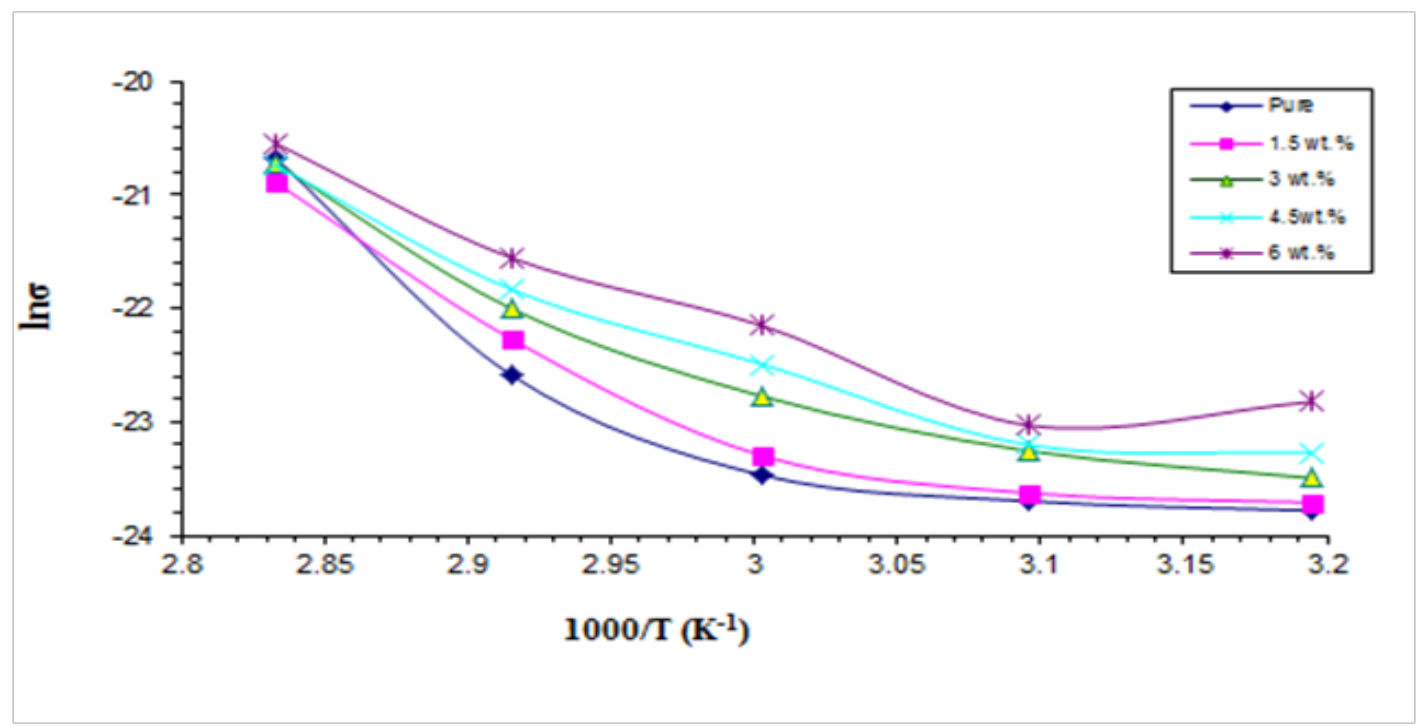

Fig. 4. Variation of $\ln (\sigma)$ and inverted absolute temperature for (PVA-MgO-SiC) nanocomposites.

$\mathrm{MgO}-\mathrm{SiC}$ ) nanocomposites with different concentrations of Silicon Carbide nanoparticles is indicated in Fig. 4. From the figure, the increase of conductivity for (PVA-MgO-SiC) nanocomposites is exponential with temperatures.
This is caused by thermal excitation of carriers into the conduction band. The electrical conductivity increases so as temperature shows many ions and electrons acquired kinetic energy via., thermally activated jumping of 
charge carriers between trapped sites, which is temperature dependence. It is suggested that in this region, the band gap between valence band and conduction band is decreased evocatively and provide easiness for electrons to jumping from valence band to conduction band [24].

The activation energy of (PVA-MgO$\mathrm{SiC}$ ) nanocomposites have high values for (PVA$\mathrm{MgO}$ ) nanocomposites, this is connected to the

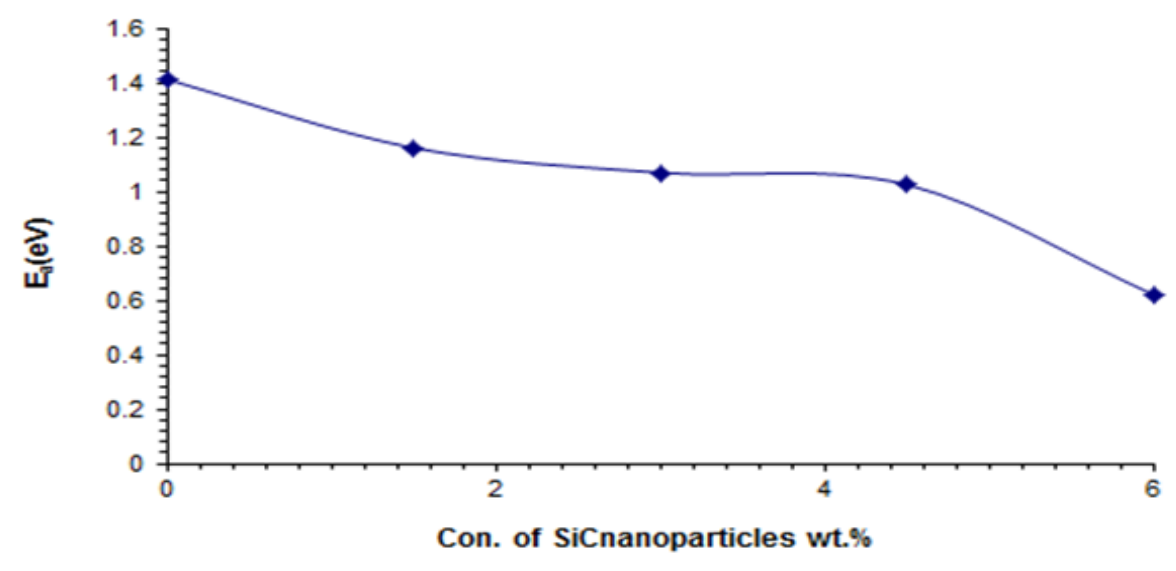

Fig. 5. Variation of activation energy for (PVA-MgO-SiC) nanocomposites with $\mathrm{SiC}$ nanoparticles concentrations.

existence of free ions in the polymer. Because of the impact of space charge and creates local energy levels in the forbidden energy [25-28], the activation energy of D.C electrical conductivity for nanocomposites decreases with increasing concentration of ( $\mathrm{SiC}$ ) nanoparticles (as indicated in Fig. 6).
In comparison with the results obtained theoretically by using Gaussian 09(G09) program and density functional theory(DFT) with (B3LYP/6-31G) basis set, the values of the total energies decrease with the increase in the number of atoms forming the nanocomposites. This result is fully compatible with the low values of the effective energies, which were calculated

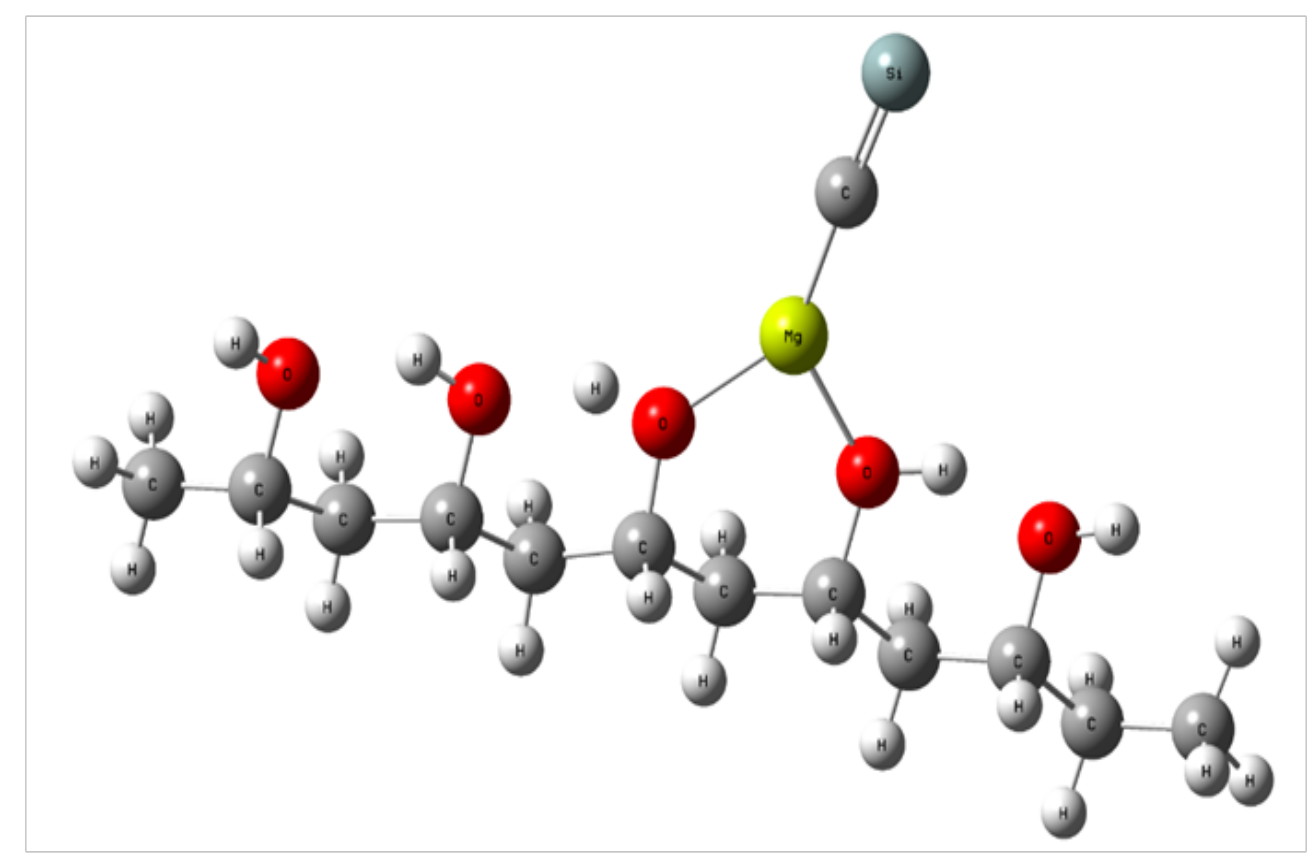

Fig. 6. Optimized geometry for (PVA-MgO-SiC) contain (46 Atoms) at the B3LYP/ 6-31G basis set. 


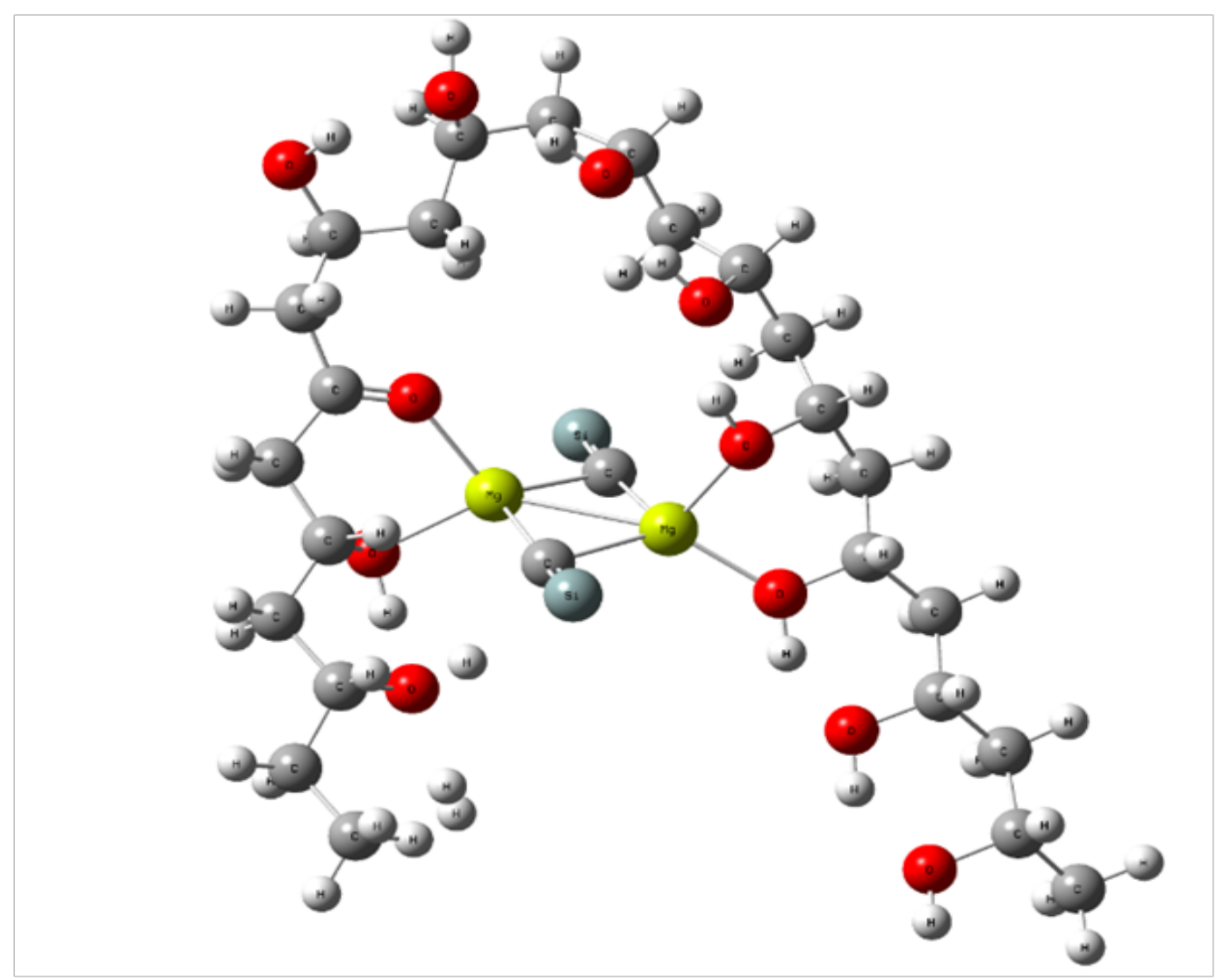

Fig. 7. Optimized geometry for (PVA-MgO-SiC) contain (91Atoms), at the, B3LYP/ 6-31G, basis set.

in practice(as shown in Fig. 6 and 7). When the number of atoms is (46 Atoms), the value of calculated total energy $(-24264.957 \mathrm{eV})$, and by increasing the number of atoms to (91 Atoms), the energy value is reduced to $(\mathbf{- 7 6 9 2 2 . 9 4 4} \mathbf{e V})$. So,

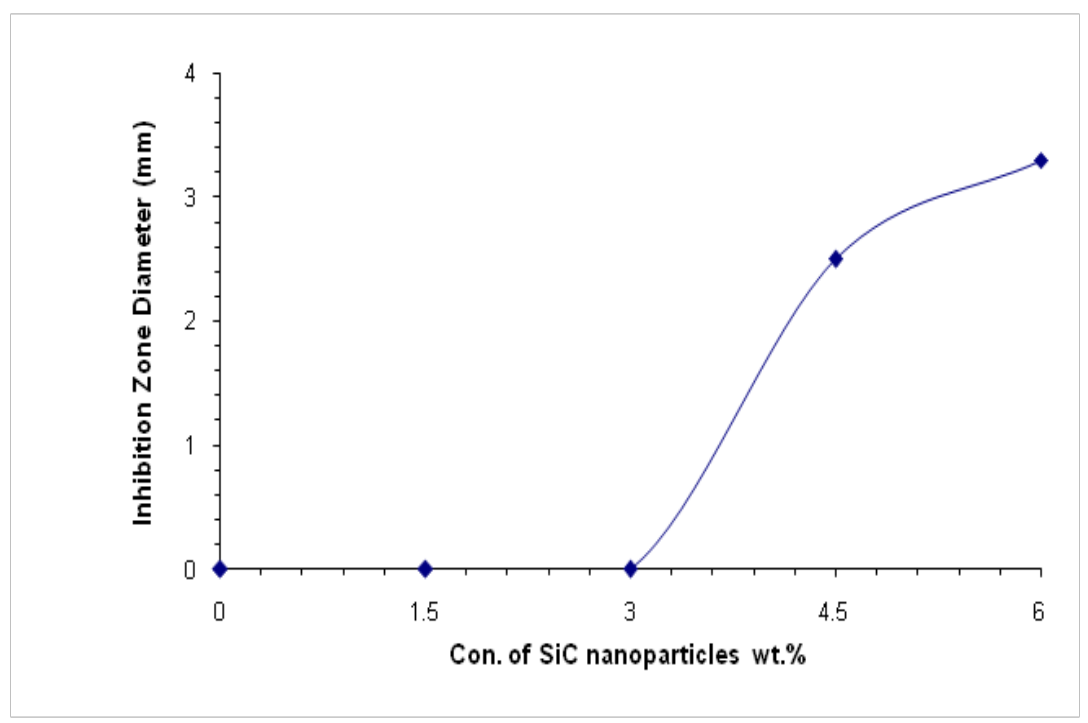

Fig. 8. Antibacterial effect of (PVA-MgO) blend as a function of SiC nanoparticles concentrations on S. aureus. 


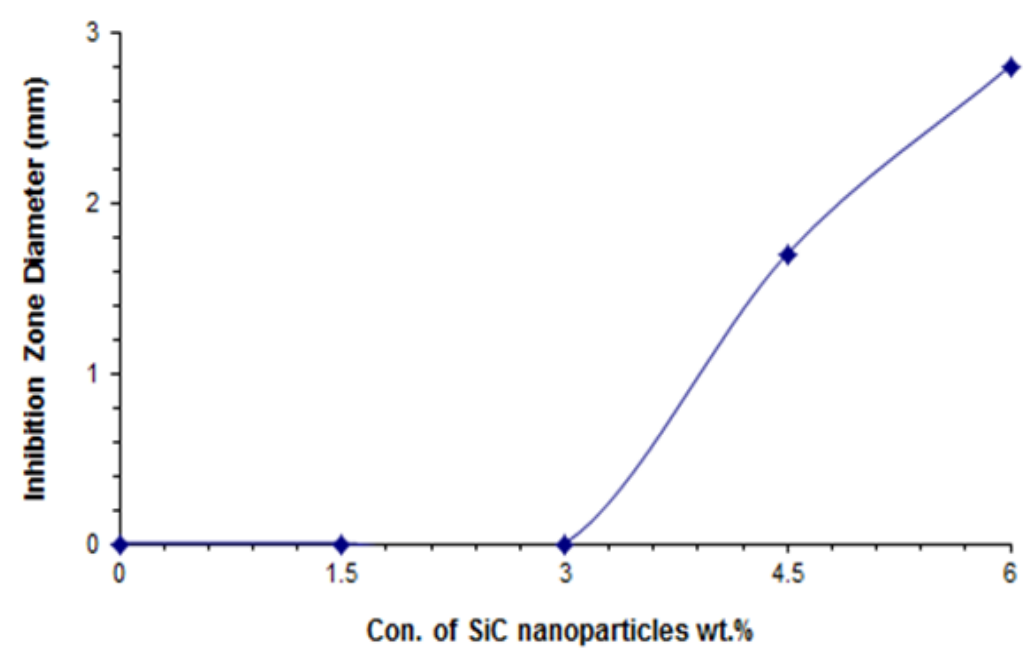

Fig. 9. Antibacterial effect of (PVA-MgO) blend as a function of SiC nanoparticles concentrations on E. coli.

the total energy values decrease with increasing number of atoms forming the composite.

The antibacterial properties of the (PVA$\mathrm{MgO}-\mathrm{SiC}$ ) nanocomposites were studied against gram-positive (Staphylococcus aureus) and gramnegative (Escherichia coli) and the gotten data are obtainable in Fig. 8 and 9.

The antibacterial mechanism of $\mathrm{MgO}$ nanoparticles is still unknown. A number of method, like the creation of reactive oxygen species (ROS), the interaction of nanoparticles with bacteria then damaging the bacterial cell [11]. Numerous studies have shown that the antibacterial mechanism of $\mathrm{MgO}$ nanoparticles is owing to the construction of ROS such as superoxide anion $\left(\mathrm{O}_{2}^{-}\right)$. It has been reported that the increase of the surface area of $\mathrm{MgO}$ particlesclues to an increase of the $\left(\mathrm{O}_{2}^{-}\right)$concentration and therefore results in a many effective damageof the cell wall of the bacteria [29]. From Fig. 11, intensity of the $\mathrm{C}=\mathrm{O}$ (carbonyl) (1700-1720 $\left.\mathrm{cm}^{-1}\right)$ stretching vibration has increased evidently. This indicates that chemical changes have occurred in the proteins in the cell wall of the bacteria[30]. $\mathrm{MgO}$ is very readily hydrated, forming a layer of $\mathrm{Mg}(\mathrm{OH})_{2}$ on the surface. Oxygen dissolved in the solution can generate superoxide anions $\mathrm{O}_{2}^{-}$by

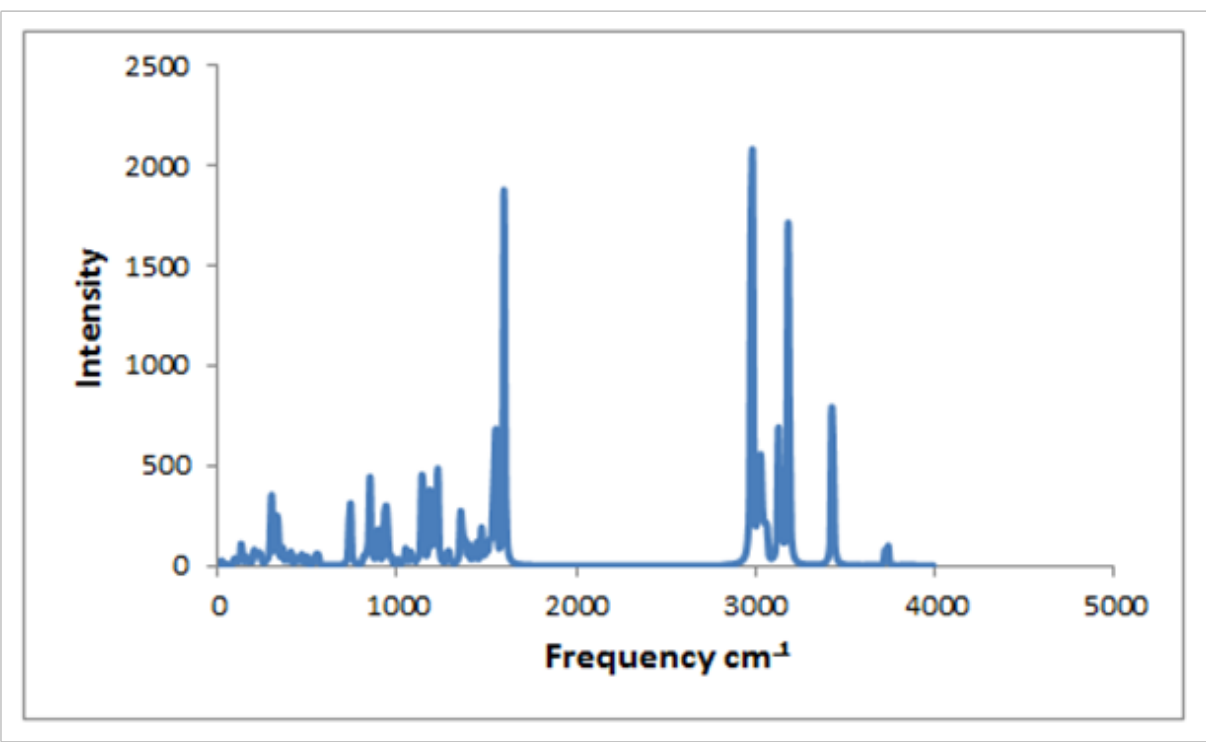

Fig. 11. IR spectrum of (PVA-MgO-SiC) nanocomposites at the, B3LYP/ 6-31G,basis set. 
single-electron reduction [31], which are stable in a basic environment. Since the surface of $\mathrm{MgO}$ is wrapped with a layer of $\mathrm{OH}^{-}$, superoxide ions can exist on the surface in high concentration. The bactericidal action of $\mathrm{MgO}$ results from attack of these superoxide ions on the $\mathrm{C}^{\delta}+$ of the carbonyl group in the peptide linkages, leading to degradation of the proteins of bacterial[32].

\section{Acknowledgement}

The authors thank the University of Babylon -Iraq (College of Education for Pure Sciences, Department of Physics and College of Science, Department of Physics).

\section{Conclusions}

The D.C. electrical conductivity of (PVA$\mathrm{MgO}$ ) blend is increased with increase the $\mathrm{SiC}$ nanoparticles concentration and temperature. The activation energy is decreased with increase the concentration of the $\mathrm{SiC}$ nanoparticles. The results obtained theoretically by using Gaussian 09(G09) program and density functional theory (DFT) with (B3LYP/6-31G) basis set showed that values of the total energies decrease with the increase in the number of atoms forming the nanocomposites and this result is fully compatible with the low values of the effective energies, which were calculated in practice. The inhibition zone for S.aureus and $E$. coli is increased with increase the concentration of $\mathrm{SiC}$ nanoparticles.

\section{References}

1. Devi, C. U., Sharma, A. K., and Rao, V. N., Electrical and optical properties of pure and silver nitrate-doped polyvinyl alcohol films. Materials Letters, 56 (3), 167-174 (2002).

2. Abdel-Malik, T. G., Abdel-Latif, R. M., Sawaby, A., and Ahmed, S. M., Electrical properties of pure and doped polyvinyl alcohol (PVA) films using gold and aluminum electrodes. Journal of Applied Sciences Research, 4 (3), 331-336 (2008).

3. Alias, A. N., Zabidi, Z. M., Ali, A. M. M., Harun, M. K., and Yahya, M.Z.A., Optical characterization and properties of polymeric materials for optoelectronic and photonic applications. International Journal of Applied Science and Technology, 3 (5), 11-38 (2013).

4. Waghmare, R. V., Belsare, N. G., Raghuwanshi, F. C., and Shilaskar, S. N., Study of dc electrical conductivity of paranitroaniline doped (1:1) polyvinylchloride and poly (methyl methacrylate)

Egypt.J.Chem. 62, No. 4 (2019) polyblends. Bulletin of Materials Science, 30 (2), 167-172 (2007).

5. Muradov, M. B., Yusifova, K. A., Eyvazova, G. M., Mammadov, R. K., and Salahova, A. Z., Study of dielectric properties of CdS/PVA nanocomposites obtained by using successive ionic layer adsorption and reaction. World Journal of Condensed Matter Physics, 3(01), 82 (2013).

6. Ahuja, T., and Kumar, D., Recent progress in the development of nano-structured conducting polymers/nanocomposites for sensor applications. Sensors and Actuators B: Chemical, 136 (1), 275-286 (2009).

7. Muradov, M. B., The influence of the type of polymer matrix on the photoluminescence from cadmium sulfide nanoparticles. Optoelectronics and Advanced Materials-Rapid Communications, 2 (2), 85-88 (2008).

8. Ghows, N., and Entezari, M. H., A novel method for the synthesis of CdS nanoparticles without surfactant. Ultrasonics Sonochemistry, 18 (1), 269275 (2011).

9. Cui, H. N., Costa, M. F., Teixeira, V., and Zhang, J., Solution-grown method of CdS film by ultrasonical colloid chemistry deposition technique. International Journal of Photoenergy, (2006), Article ID: 24916. doi:10.1155/IJP/2006/24916.

10. Gandhi, S., Abiramipriya, P., Pooja, N., Jeyakumari, J. J. L., Arasi, A. Y., Dhanalakshmi, V., and Anbarasan, R., Synthesis and characterizations of nano sized $\mathrm{MgO}$ and its nano composite with poly (vinyl alcohol). Journal of Non-Crystalline Solids, 357(1), 181-185 (2011).

11. Tang, Z. X., and Lv, B. F., MgO nanoparticles as antibacterial agent: Preparation and activity. Brazilian Journal of Chemical Engineering, 31(3), 591-601 (2014).

12. Li, Z., Zhou, W., Su, X., Luo, F., Zhu, D., and Liu, P., Preparation and Characterization of Aluminum-Doped Silicon Carbide by Combustion Synthesis. Journal of the American Ceramic Society, 91(8), 2607-2610 (2008).

13. Shi, X., Dong, Y., Xu, F., Tan, Y., Wang, L., and Yang, J. M., Preparation and properties of nano-SiC strengthening $\mathrm{Al} 2 \mathrm{O} 3$ composite ceramics. Materials Science and Engineering: A, 528 (6), 2246-2249 (2011).

14. Yang, Q., and Troczynski, T., Alumina Sol-Assisted 
Sintering of $\mathrm{SiC}-\mathrm{A} 12 \mathrm{O} 3$ Composites. Journal of the American Ceramic Society, 83 (4), 958-960 (2000).

15. Ham, D. J., and Lee, J. S., Transition metal carbides and nitrides as electrode materials for low temperature fuel cells. Energies, 2 (4), 873-899 (2009).

16. Huang, Z., Maness, P. C., Blake, D. M., Wolfrum, E. J., Smolinski, S. L., \& Jacoby, W. A., Bactericidal mode of titanium dioxide photocatalysis. Journal of Photochemistry and Photobiology A: Chemistry, 130 (2-3), 163-170 (2000).

17. Atkins, P., and De Paula, J. Physical Chemistry for The Life Sciences. Oxford University Press, USA (2011).

18. Sholl, D., and Steckel, J. A., Density Functional Theory: A Practical Introduction. John Wiley \& Sons (2011)

19. Gaussian, R. A. 03, MJ Frisch, GW Trucks, HB Schlegel, GE Scuseria, MA Robb, JR Cheeseman, JA Montgomery, Jr. T. Vreven, KN Kudin, JC Burant, JM Millam, SS Iyengar, J. Tomasi, V. Barone, B. Mennucci, M. Cossi, G. Scalmani, N. Rega, GA Pet, Journal of Molecular Structure, 666, 31-39 (2003).

20. Gaussian, R. A. 1, MJ Frisch, GW Trucks, HB Schlegel, GE Scuseria, MA Robb, JR Cheeseman, G. Scalmani, V. Barone, B. Mennucci, GA Petersson et al., Gaussian. Inc., Wallingford CT, 121, 150166 (2009).

21. Pandey, M., Joshi, G. M., Deshmukh, K., and Ahmad, J., Impedance spectroscopy and conductivity studies of $\mathrm{CdCl} 2$ doped polymer electrolyte. Advanced Materials Letters, 6 (2), 165171 (2015).

22. Waghmare, R. V., Belsare, N. G., Raghuwanshi, F. C., and Shilaskar, S. N., Study of dc electrical conductivity of paranitroaniline doped (1: 1) polyvinylchloride and poly (methyl methacrylate) polyblends. Bulletin of Materials Science, 30 (2), 167-172 (2007).

23. Srikanth, C., Sridhar, C., Nagabhushana, B. M., \& Mathad, R. D., Characterization and DC conductivity of novel $\mathrm{CuO}$ doped polyvinyl alcohol (PVA) nano-composite films. J Eng Res Appl, 4 (10), 38-46 (2014).

24. Harun, M. H., Saion, E., Kassim, A., Hussain, M.
Y., Mustafa, I. S., and Omer, M. A. A., Temperature Dependence of AC Electrical Conductivity of PVAPPy-FeCl3 Composite Polymer Films, Iskandar Shahrim Mustafa2 and Muhd Ahmad Ali Omer 2. Malaysian Polymer Journal, 3 (2), 24-31 (2008).

25. Reda, S. M., and Al-Ghannam, S. M., Synthesis and electrical properties of polyaniline composite with silver nanoparticles. Advances in Materials Physics and Chemistry, 2 (2), 75-81 (2012).

26. Hashim A. and Hadi Q., Structural, electrical and optical properties of (biopolymer blend/ titanium carbide) nanocomposites for low cost humidity sensors. Journal of Materials Science: Materials in Electronics, 29, 11598-11604 (2018).

27. Hashim A. and Hadi Q., Synthesis of Novel (Polymer Blend-Ceramics) Nanocomposites: Structural, Optical and Electrical Properties for Humidity Sensors. Journal of Inorganic and Organometallic Polymers and Materials, 28 (4), 1394-1401 (2018).

28. Hashim A. and Hadi A., Novel Pressure Sensors Made From Nanocomposites (Biodegradable Polymers-Metal Oxide Nanoparticles): Fabrication And Characterization. Ukrainian Journal of Physics, 63 (8) (2018).

29. Hashim A., Agool I. R. and Kadhim K. J., Novel of (Polymer Blend- $\mathrm{Fe}_{3} \mathrm{O}_{4}$ ) Magnetic Nanocomposites: Preparation and Characterization For Thermal Energy Storage and Release, Gamma Ray Shielding, Antibacterial Activity and Humidity Sensors Applications. Journal of Materials Science: Materials in Electronics, 29 (12), 10369 10394 (2018).

30. Huang, L., Li, D. Q., Lin, Y. J., Wei, M., Evans, D. G., and Duan, X., Controllable preparation of Nano-MgO and investigation of its bactericidal properties. Journal of Inorganic Biochemistry, 99 (5), 986-993 (2005).

31. Sawai, J., Kojima, H., Igarashi, H., Hashimoto, A., Shoji, S., Sawaki, T. and Shimizu, M., Antibacterial characteristics of magnesium oxide powder. World Journal of Microbiology and Biotechnology, 16(2), 187-194 (2000).

32. Yamamoto, O., Sawai, J., and Sasamoto, T., Change in antibacterial characteristics with doping amount of $\mathrm{ZnO}$ in $\mathrm{MgO}-\mathrm{ZnO}$ solid solution. International Journal of Inorganic Materials, 2 (5), 451-454 (2000). 


\section{تحليل الخصائص التركيبية، والكهربائية والاككترونية ل (متر اكبات نانوية بوليمرية / كاربيد السليكون) للتطبيقات مضادات البكتريا

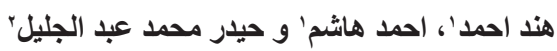

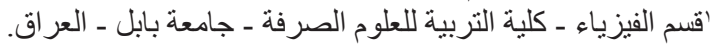

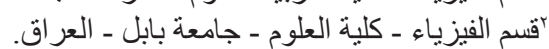

تم تحقيق الخصائص التركيبية، و الالكترونية و الكهربائية المستمرة للمتر اكبات النانوية (PVA-MgO-SiC)

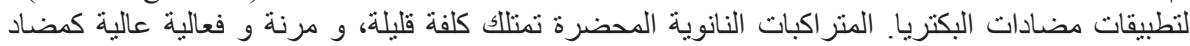

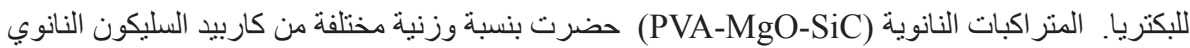
(PiC) (PVA-MgO-SiC) درست بدرجات حرارة مختلفة.

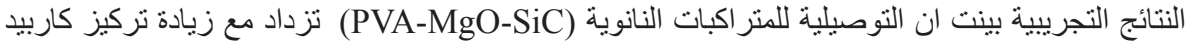

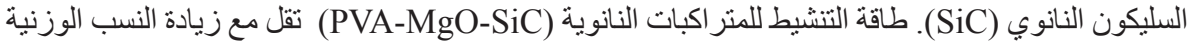

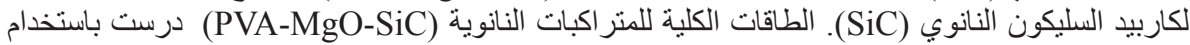

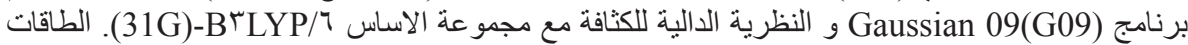
الكلية تقل مع زيادة عدد الذرت المكونة للمتر اكبات النانوية. 